\title{
Clostridium magnum sp. nov., a non-autotrophic homoacetogenic bacterium
}

\author{
Bernhard Schink \\ Fakultät für Biologie, Universität Konstanz, Postfach 5560, D-7750 Konstanz, Federal Republic of Germany
}

\begin{abstract}
A new mesophilic, sporeforming, strictly anaerobic bacterium was isolated from enrichments with 2,3butanediol as sole substrate and pasteurized freshwater sediment as inoculum. Cells were large, motile rods, and elliptical spores were formed subterminally or centrally. They stained Gram-negative, but no typical outer membrane layer could be observed by electron microscopy of ultrathin sections. 2,3-Butanediol, acetoin, fructose, glucose, sucrose, xylose, malate and citrate served as substrates and were completely converted to acetate with concomitant reduction of carbon dioxide. Growth on glucose $\left(t_{\mathrm{d} \text { min }}=1.4 \mathrm{~h}\right)$ was faster than on butanediol $\left(t_{\mathrm{d} \text { min }}=3.6 \mathrm{~h}\right)$. No growth occurred on hydrogen/carbon dioxide, on formate or on methanol. The guanine plus cytosine content of the DNA was $29.1 \%$. The new isolate is described as a new species, Clostridium magnum sp. nov.
\end{abstract}

Key words: Clostridium magnum Species description - 2,3Butanediol - Anaerobic degradation - Homoacetogenic fermentation - Syntrophic substrate degradation Butanediol formation

2,3-Butanediol is an end product of anaerobic fermentations, and degradative systems for this compound have to be postulated in anaerobic ecosystems. In a former paper (Schink 1983), two types of butanediol-degrading anaerobes were described. Both apparently cleaved the butanediol molecule between the carbon atoms 2 and 3 . The $\mathrm{C}_{2}$ residues thus obtained were either disproportionated to acetate and ethanol or to acetate and propionate in a so far unknown reaction including net reduction of carbon dioxide. Since butanediol is a highly reduced fermentation product, it could also be a suited substrate for homoacetogenic carbon dioxide reduction. In the present paper, a new homoacetogenic bacterium is described which was isolated with butanediol as sole substrate. The importance of butanediol formation and its anaerobic degradation has been discussed earlier (Schink 1983).

\section{Materials and methods}

All procedures for cultivation and isolation as well as all methods for analysis of metabolic products and of degradative enzymes were exactly as described in earlier papers (Widdel and Pfennig 1981; Schink and Pfennig 1982; Schink 1983). The mineral medium for enrichment and further cultivation contained $30 \mathrm{mM}$ sodium bicarbonate as buffer, sodium sulfide as reducing agent, and the new trace element solution SL 10 (Widdel et al. 1983). The pH was 7.2-7.4. Growth experiments were carried out at $28^{\circ} \mathrm{C}$. For isolation of pure cultures, the agar shake culture method (Pfennig 1978) was applied. All chemicals were of reagent grade quality and obtained from Merck, Darmstadt, FRG; Serva, Heidelberg, FRG; and Fluka, Neu-Ulm, FRG.

\section{Results \\ Enrichment and isolation}

$50 \mathrm{ml}$ enrichments in freshwater medium with $10 \mathrm{mM}$ 2,3-butanediol as substrate were inoculated with $3-5 \mathrm{ml}$ of pasteurized $\left(15 \mathrm{~min}\right.$ at $80^{\circ} \mathrm{C}$ ) black, anoxic mud from creeks and sewage plants. Gas pressure, probably due to acidification ( $\mathrm{pH}$ 6.0-6.2) developed after 7-14 days. In subcultures on the same medium, turbidity was observed after $2-5$ days, and the $\mathrm{pH}$ dropped again remarkably. Microscopically, long fat rods and several free elliptical spores could be observed. After two further transfers, cultures were subjected to two subsequent dilution series in agar shake cultures. Colonies in agar medium were lens-shaped and slightly yellowish in colour. Two pure cultures were isolated from the last positive dilution tubes derived from creek sediments (strains Wo Bd P1, Wo Bd P2) and one from sewage sludge (Ko Bd P1). All strains looked similar in the microscope, and all produced only acetate from butanediol. Strain Wo Bd P1 was subjected to further characterization.

\section{Characterization of strain $W o B d P 1$}

Strain Wo Bd P 1 grew well in the mineral medium described. Vitamins or the trace elements selenium or tungstene were not required. Aged cultures often exhibited long lag phases before growth started. These lags could be shortened by addition of a trace of dry sodium dithionite (Widdel and Pfennig 1977). Sodium chloride inhibited growth at $1 \%$ $(0.17 \mathrm{mM})$ concentration, potassium phosphate at $20 \mathrm{mM}$ concentration. Yeast extract or any other suppline was not required for growth and did not enhance growth yields.

\section{Morphology}

In phase contrast microscopy, cells appeared as long, fat, straight rods with slightly pointed ends, $1.0-1.5 \times 4-16 \mu \mathrm{m}$ in size (Fig. 1 a). During growth on glucose or fructose, cells swell in the middle and became spindle-like with diameters 

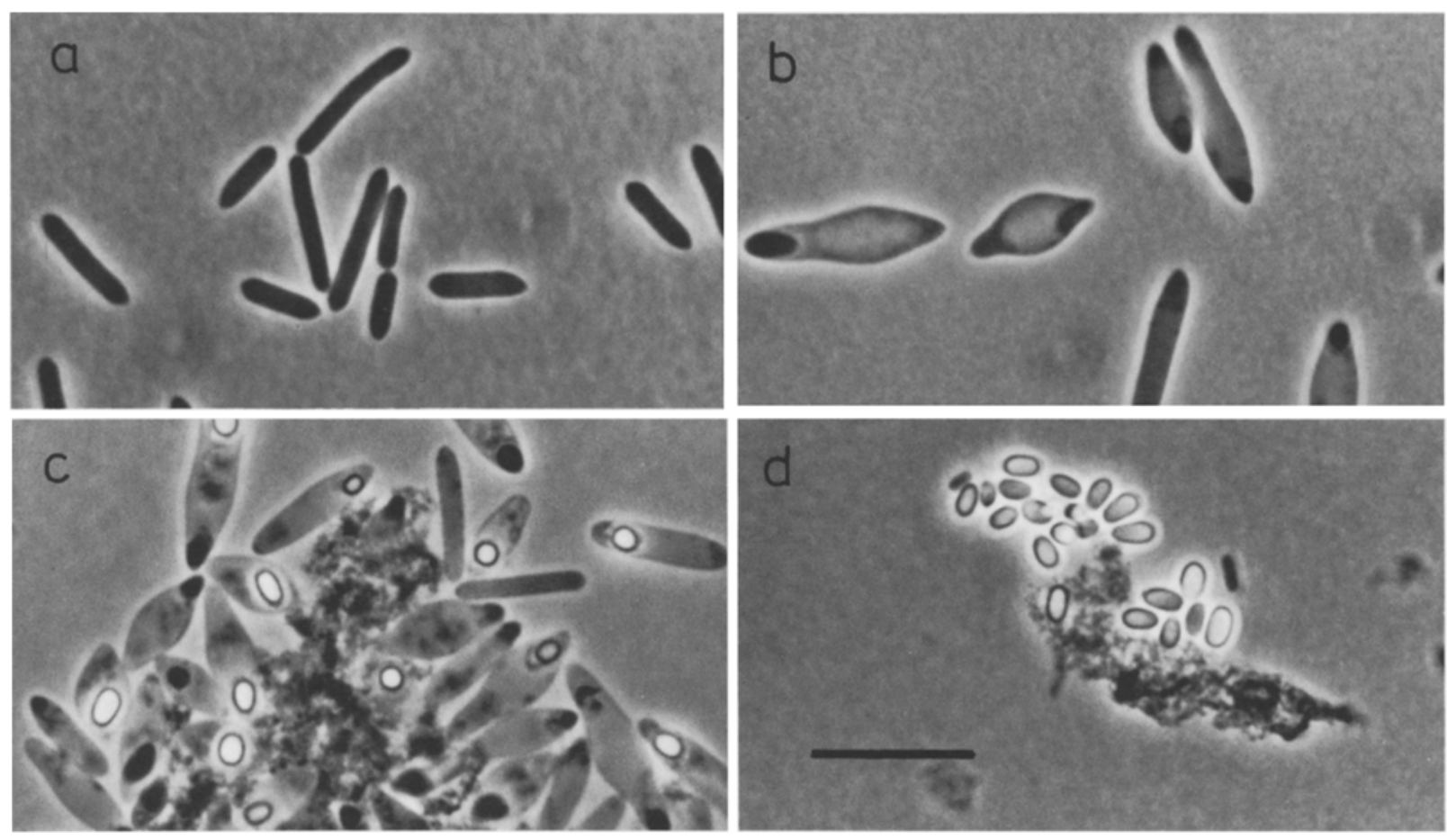

Fig. 1 a-d. Phase contrast photomicrographs of Clostridium magnum strain Wo Bd P1. Bar equals $10 \mu \mathrm{m}$ for all panels. a Log-phase cells growing on butanediol. b Glucose-grown cells at the beginning of the stationary phase. $\mathbf{c}$ Spore formation in the late stationary phase after growth on glucose. d Free spores associated with precipitates of iron sulfide after growth on glucose

up to $4 \mu \mathrm{m}$ (Fig. $1 \mathrm{~b}$ ). Dark elliptical zones could be observed at the spindle tips. Burke's $\mathrm{KJ} \cdot \mathrm{J}_{2}$ solution stained the central part of these cells deep brown indicating the presence of a glycogen-like polysaccharide, whereas the cell tips remained unstained. No polysaccharide staining was observed in butanediol-grown cells. Spore formation occurred in the central to subterminal region (Fig. 1c). Spores were elliptical, $1.5 \times 2.5 \mu \mathrm{m}$ in size, and were released only very late after growth on glucose (Fig. $1 \mathrm{~d}$ ). Addition of soil extract did not significantly accelerate spore formation. Spore germination in fresh media was facilitated by addition of a trace of sodium dithionite. Growing cells were motile and lost motility in ageing cultures. Casually attached particles revealed that moving cells rotated slowly several times in one sense until the swimming direction was changed, a feature which suggests polar flagellation. Flagella staining after Mayfield and Inniss (1977) revealed polar and subpolar flagella.

Cells stained Gram-negative, however, electron microscopic observation of ultra-thin sections gave no indication for the presence of an outer lipopolysaccharide membrane as typical of Gram-negative bacteria. Rather, the cell wall architecture was similar to Gram-positive bacteria (Fig. 2) with a rather thin murein layer.

The guanine plus cytosine content of the DNA was determined to be $29.1 \pm 0.5 \mathrm{~mol} \% \mathrm{G}+\mathrm{C}$. No cytochromes were detected in crude cell extracts or membrane fractions of butanediol-grown cells by redox difference spectroscopy.

\section{Physiology and stoichiometry of fermentation}

Besides on butanediol, strain Wo Bd P1 grew also on acetoin, malate, citrate, glucose, fructose, sucrose and

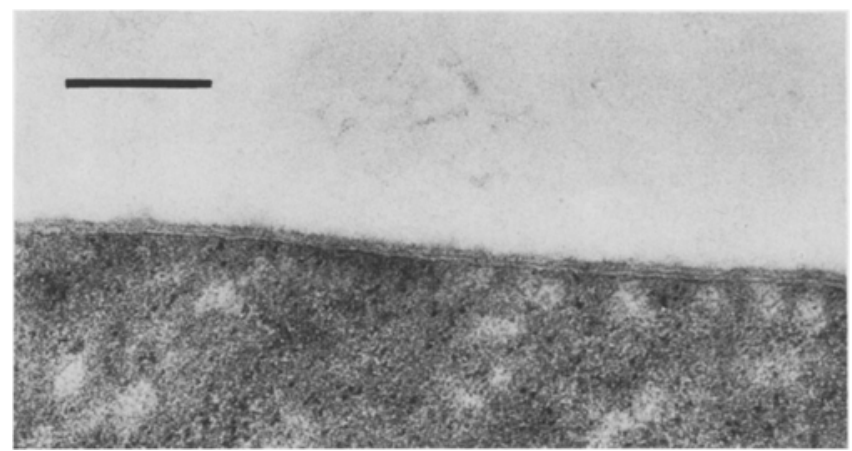

Fig. 2. Electron micrographs of an ultra-thin section of Clostridium magnum strain Wo Bd P1 showing cell wall architecture. Bar equals $0.2 \mu \mathrm{m}$

xylose. Growth on $\mathrm{C}_{1}$ compounds like $\mathrm{H}_{2} / \mathrm{CO}_{2}$, formate, or methanol was not observed, neither in the presence nor in the absence of $5 \mathrm{mM}$ acetate although butanediol-grown cells exhibited benzyl viologen-dependent hydrogenase activity in the range of $10-50$ units per gram protein. In Table 1, growth substrates of strain Wo Bd P1 and those of other mesophilic homoacetogenic bacteria are compared. Further substrates tested for growth are listed in the species description at the end of the Discussion section.

The only fermentation product detected was acetate. Acetate formation accounted for all reducing equivalents provided with the substrate (Table 2), according to the following fermentation equations (calculations of free energy changes after Thauer et al. 1977; $\Delta \mathrm{Gf}_{0}$ values for butanediol, $-321.8 \mathrm{~kJ} / \mathrm{mol}$, and for acetoin, $-279.7 \mathrm{~kJ} /$ 
Table 1. Substrates utilized by strain Wo Bd P1 and by other mesophilic homoacetogenic anaerobes

\begin{tabular}{|c|c|c|c|c|}
\hline Substrate & $\begin{array}{l}\text { Strain } \\
\text { Wo Bd P1 }{ }^{a}\end{array}$ & $\begin{array}{l}\text { Clostridium } \\
\text { formico- } \\
\text { aceticum }^{\mathrm{a}}\end{array}$ & $\begin{array}{l}\text { Clostridium } \\
\text { aceticum }^{\mathrm{b}}\end{array}$ & $\begin{array}{l}\text { Aceto- } \\
\text { bacterium } \\
\text { woodii } \mathrm{c}\end{array}$ \\
\hline $\mathrm{H}_{2} / \mathrm{CO}_{2}$ & - & - & + & + \\
\hline Formate & - & - & + & + \\
\hline Methanol & - & + & - & $+^{d}$ \\
\hline $\begin{array}{l}\text { Ethylene } \\
\text { glycol }\end{array}$ & - & - & + & $+{ }^{e}$ \\
\hline Ethanol & - & + & + & - \\
\hline Serine & - & - & + & - \\
\hline Lactate & - & + & - & $(+)^{\mathrm{f}}$ \\
\hline Pyruvate & \pm & \pm & + & + \\
\hline Malate & $\overline{+}$ & $\overline{+}$ & + & - \\
\hline Fumarate & - & \pm & + & - \\
\hline Citrate & + & \pm & - & $-^{d, g}$ \\
\hline Glycerate & - & + & - & - \\
\hline Glycerol & - & + & - & + \\
\hline Glutamate & - & + & + & - \\
\hline Fructose & + & + & + & + \\
\hline Glucose & + & - & - & $(+)^{f}$ \\
\hline Arabinose & - & - & n.d. & $-\mathrm{g}$ \\
\hline Xylose & + & - & - & $-\mathrm{g}$ \\
\hline Ribose & - & + & + & - \\
\hline $\begin{array}{l}\text { 2,3-Butane- } \\
\text { diol }\end{array}$ & & & +8 & $(+)^{\mathrm{f}, \mathrm{g}}$ \\
\hline Acetoin & $\begin{array}{l}+ \\
+\end{array}$ & $\begin{array}{l}\text { n.d. } \\
\text { n.d. }\end{array}$ & $+g$ & $(+)^{\mathrm{f}, \mathrm{g}}$ \\
\hline
\end{tabular}

a Data from Andreesen et al. 1970

b Data from Braun et al. 1981 and Adamse 1980

- Data from Baich et al. 1977

d After Bache and Pfennig 1981

e After Schink and Stieb 1983

f Not all strains grow on this substrate

gesults of this study n.d. means not determined

mol, were calculated by comparison with other alcohols and ketones):

Butanediol-2,3:

$4 \mathrm{CH}_{3} \mathrm{CHOHCHOHCH}+3 \mathrm{HCO}_{3}^{-} \rightarrow$ $11 \mathrm{CH}_{3} \mathrm{COO}^{-}+5 \mathrm{H}^{+}+4 \mathrm{H}_{2} \mathrm{O}$

$\Delta \mathrm{G}_{0}^{\prime}=-101.7 \mathrm{~kJ} / \mathrm{mol}$

Acetoin:

$2 \mathrm{CH}_{3} \mathrm{COCHOHCH}_{3}+2 \mathrm{HCO}_{3}^{-} \rightarrow$

$5 \mathrm{CH}_{3} \mathrm{COO}^{-}+3 \mathrm{H}^{+}$

$\Delta \mathrm{G}_{0}^{\prime}=-118.37 \mathrm{~kJ} / \mathrm{mol}$

Fructose, glucose:

$\mathrm{C}_{6} \mathrm{H}_{12} \mathrm{O}_{6} \rightarrow 3 \mathrm{CH}_{3} \mathrm{COO}^{-}+3 \mathrm{H}^{+}$

$\Delta \mathrm{G}_{0}^{\prime}=-312.7 \mathrm{~kJ} / \mathrm{mol}$

Malate:

$2 \mathrm{C}_{4} \mathrm{H}_{4} \mathrm{O}_{5}^{2-}+2 \mathrm{H}_{2} \mathrm{O} \rightarrow$

$3 \mathrm{CH}_{3} \mathrm{COO}^{-}+2 \mathrm{HCO}_{3}^{-}+\mathrm{H}^{+}$

$\Delta \mathrm{G}_{0}^{\prime}=-78.8 \mathrm{~kJ} / \mathrm{mol}$

Citrate:

$4 \mathrm{C}_{6} \mathrm{H}_{5} \mathrm{O}_{7}^{3-}+8 \mathrm{H}_{2} \mathrm{O} \rightarrow$

$9 \mathrm{CH}_{3} \mathrm{COO}^{-}+6 \mathrm{HCO}_{3}^{-}+3 \mathrm{H}^{+}$.

$\Delta \mathrm{G}_{0}^{\prime}=-98.8 \mathrm{~kJ} / \mathrm{mol}$
Enzymes involved in butanediol degradation were assayed in crude extracts of butanediol-grown cells. The results are presented in Table 3. Acetoin dehydrogenase, phosphate acetyl transferase and acetate kinase were found in high specific activities, whereas no butanediol dehydrogenase activity could be detected. It has to be assumed that this enzyme cannot be assayed for in this organism by standard procedures, however, its presence has to be postulated. Nonetheless, the results indicate that butanediol was degraded via cleavage into two $C_{2}$ units which were subsequently oxidized to acetate with concomitant ATP synthesis.

Strain Wo Bd P1 was strictly anaerobic. No growth occurred in the presence of traces of oxygen as visualized in oxygen gradient tube cultures. Neither nitrate, nor sulfate, sulfur, thiosulfate, sulfite, or fumarate were reduced. Growth was possible at temperatures higher than 15 and lower than $45^{\circ} \mathrm{C}$; the optimum was at $30-32^{\circ} \mathrm{C}$. The $\mathrm{pH}$ optimum was around $\mathrm{pH} 7.0$; no growth occurred at $\mathrm{pH} 7.8$ or $\mathrm{pH} 6.0$. Under optimal conditions, the doubling time was $1.4 \mathrm{~h}$ on glucose $\left(\mu_{\max }=0.495 \mathrm{~h}^{-1}\right)$ and $3.6 \mathrm{~h}$ on butanediol $\left(\mu_{\max }=0.192 \mathrm{~h}^{-1}\right)$.

If carbonate-free, phosphate-buffered medium was used, 2,3-butanediol and ethanol were formed from glucose as reduced end products, together with acetate, however, growth was poor under these conditions. Butanediol was not degraded in carbonate-free medium.

In cultures with Methanospirillum hungatei, strain Wo Bd P1 degraded butanediol to less acetate than in pure culture. The amount of methane formed indicated that about one third of the electrons released during butanediol oxidation to acetate were transferred to the methanogen via interspecies hydrogen transfer.

\section{Discussion}

Physiology

After Wieringa's discovery of the homoacetogenic metabolism and the description of the autotrophic Clostridium aceticum (1940), it took more than a quarter of a century until other homoacetogenic bacteria were isolated. Not all of these isolates were able to grow autotrophically. Besides C. aceticum (Adamse 1980; Braun et al. 1981), only Acetobacterium woodii (Balch et al. 1977), A, wieringae (Braun and Gottschalk 1982) Acetogenium kivui (Leigh et al. 1981) and an unidentified Clostridium strain (Adamse and Velzeboer 1982) are able to grow on hydrogen/carbon dioxide or formate whereas C. formicoaceticum (Andreesen et al. 1970) and C. thermoaceticum (Fontaine et al. 1942) depend on organic growth substrates, at least methanol. The main physiological advantage of the homoacetogenic over other fermenting bacteria is their ability to use bicarbonate as an external electron acceptor which is usually present in high excess in anoxic sediments. Other fermentations which use bicarbonate as electron acceptor lead to the formation of either propionate (Samain et al. 1982; Laanbroek et al. 1982; Schink 1983) or acetate and butyrate (Zeikus et al. 1980; Sharak Genthner et al. 1981) as reduced end products. The reduction of bicarbonate allows a concomitant oxidation of the organic substrate to acetate and enhances considerably the yield of metabolic energy conserved. Homoacetogenic bacteria are less efficient in hydrogen scavenging than methanogens which use the same electron acceptor. 
Table 2. Growth yields and stoichiometry of fermentation by strain Wo Bd P1. All figures are means of at least two independent assays. Production and utilization of carbon dioxide was calculated according to the fermentation equations given in the "Results" section

\begin{tabular}{|c|c|c|c|c|c|c|c|c|}
\hline Substrate & $\begin{array}{l}\text { Concen- } \\
\text { tration } \\
\mu \mathrm{mol} / \mathrm{ml}\end{array}$ & $\begin{array}{l}\text { Amount of } \\
\text { substrate } \\
\text { used } \mu \mathrm{mol}\end{array}$ & $\begin{array}{l}\mathrm{OD}_{650} \\
\text { reached }\end{array}$ & $\begin{array}{l}\text { Cell dry } \\
\text { weight } \\
\text { formed mg }\end{array}$ & $\begin{array}{l}\text { Acetate } \\
\text { assimi- } \\
\text { lated } \\
\mu \mathrm{mol}\end{array}$ & $\begin{array}{l}\text { Acetate } \\
\text { formed } \\
\mu \text { mol }\end{array}$ & $\begin{array}{l}\text { Growth } \\
\text { yield } \\
\text { mg/mmol } \\
\text { substrate } \\
\text { utilized }\end{array}$ & $\begin{array}{l}\text { Carbon } \\
\text { recovery } \\
\%\end{array}$ \\
\hline 2,3-Butanediol & 10 & 200 & 0.33 & 1.41 & 29.0 & 515.2 & 7.05 & 98.9 \\
\hline Acetoin & 10 & 200 & 0.37 & 1.58 & 32.5 & 477.9 & 7.90 & 102.1 \\
\hline Fructose & 2 & 40 & 0.44 & 1.88 & 38.7 & 90.2 & 47.0 & 107.4 \\
\hline Glucose & 2 & 40 & 0.45 & 1.93 & 39.7 & 88.4 & 48.2 & 106.8 \\
\hline Xylose & 6.6 & 133 & 1.10 & 4.7 & 96.8 & 230.0 & 35.3 & 98.3 \\
\hline Citrate & 10 & 200 & 0.21 & 0.90 & 18.5 & 452.8 & 4.5 & 104.7 \\
\hline
\end{tabular}

Experiments were carried out in $20 \mathrm{ml}$ glass tubes sealed with screw caps. Cell dry weights were determined in $500 \mathrm{ml}$ calibration cultures, and were calculated in individual tubes via cell density $\left(\mathrm{OD}_{650}=0.1\right.$ corresponded to $21.4 \mathrm{mg}$ dry cell material per 1$)$. Acetate assimilated into cell material was calculated by the equation; $17 \mathrm{CH}_{3} \mathrm{COOH} \rightarrow 8<\mathrm{C}_{4} \mathrm{H}_{7} \mathrm{O}_{3}>+2 \mathrm{CO}_{2}+6 \mathrm{H}_{2} \mathrm{O}$; thus, $20.6 \mu$ mol acetate is required for $1.0 \mathrm{mg}$ of cell dry weight

Table 3. Catabolic enzymes involved in 2,3-butanediol degradation by Clostridium magnum strain Wo Bd P1

\begin{tabular}{|c|c|c|}
\hline Enzyme & $\begin{array}{l}\text { E.C. } \\
\text { number }\end{array}$ & $\begin{array}{l}\text { Specific activity } \\
\left(\mu \mathrm{mol} \cdot \min ^{-1} \cdot \text { mg protein }^{-1}\right)\end{array}$ \\
\hline $\begin{array}{l}\text { Butanediol } \\
\text { dehydrogenase }\end{array}$ & $1.1 .1 .4(?)$ & $<0.001$ \\
\hline $\begin{array}{l}\text { Acetoin } \\
\text { dehydrogenase }\end{array}$ & 1.1 .1 .5 & 0.129 \\
\hline $\begin{array}{l}\text { Phosphate } \\
\text { acetyl } \\
\text { transferase }\end{array}$ & 2.3 .1 .8 & 8.84 \\
\hline Acetate & & \\
\hline kinase & 2.7.2.1 & 3.08 \\
\hline
\end{tabular}

Assay of enzymes was performed in crude extracts as described in detail (Schink 1983). $20-1100 \mu \mathrm{g}$ protein were applied per assay

Their ecological advantage in nature, however, is probably their metabolic versatility which allows them to grow on various kinds of reduced substrates independent of syntrophic cooperations with e. g. methanogenic bacteria.

In the present study, anaerobic enrichment cultures were started with 2,3-butanediol, a reduced end product of anaerobic fermentations. When untreated anoxic sediment was used as inoculum on this substrate, two different metabolic types of strictly anaerobic bacteria were obtained in pure culture: one type isolated from marine sediments, Pelobacter carbinolicus, carried out a disproportionation reaction leading to ethanol and acetate as products, whereas the other type isolated from freshwater sources, Pelobacter propionicus, fermented butanediol to acetate and propionate with concomitant reduction of one mol bicarbonate per mol butanediol (Schink 1983). On the basis of the fermentation pattern and the results of enzyme assays butanediol was found to be degraded via oxidation and cleavage into two $\mathrm{C}_{2}$ units which underwent different disproportionation reactions. The growth yield of the propionate-forming organism $(6.2 \mathrm{~g} / \mathrm{mol})$ was nearly twice as high as that of the ethanol-forming organism $(3.6 \mathrm{~g} / \mathrm{mol})$ indicating that the reduction of bicarbonate in this so far unknown reaction allows a higher energy yield than the fermentation to ethanol and acetate.
The organism isolated in the present study was an unusually large Clostridium sp. which degraded butanediol to acetate as sole product. Degradation of butanediol probably followed a similar pathway as assumed for $P$. carbinolicus and $P$. propionicus. Oxidation by butanediol dehydrogenase and acetoin dehydrogenase allowed thiolytic cleavage of the resulting molecule into acetyl-CoA and an acetaldehyde residue which was probably further oxidized to acetate via acetyl-CoA. The butanediol preparation used contained about $80 \%$ of the meso- and about $10 \%$ of each the $L(+)-$ and the $\mathrm{D}(-)$-enantiomer (communication by Fluka Chemical Co.). Since complete degradation of this stereoisomer mixture was observed and butanediol dehydrogenases are reported to be strictly stereospecific (Taylor and Juni 1960; Höhn-Bentz and Radler 1978), at least one racemase enzyme has to be postulated.

The stoichiometry of butanediol degradation by pure cultures of strain Wo $\mathrm{Bd} P 1$ revealed that the reducing equivalents obtained during oxidation of butanediol to two molecules of acetate were used for a homoacetogenic bicarbonate reduction. In coculture with a hydrogen-utilizing methanogen, about one third of the electrons obtained during butanediol oxidation were released as free hydrogen thus indicating that the hydrogenase activity found allows this organism to participate in interspecies hydrogen transfer either via proton reduction or hydrogen oxidation. In the absence of sufficient carbonate, the butanediol-oxidizing enzyme system could also be used for reductive butanediol formation thus again illustrating the metabolic versatility of this new isolate.

The cell yields obtained after growth on various substrates (Table 2) so far only allow preliminary considerations on the metabolic efficiency. The yields on fructose and glucose are similar to that obtained with $A$. woodii on glucose (Tschech and Pfennig 1983) and are in accordance with conservation of $5-6$ mol ATP per mol sugar assuming a yield coefficient of about $10 \mathrm{~g}$ cell dry weight per mol ATP (Stouthamer, 1979). The yield on xylose is slightly lower corresponding to a smaller energy yield available from $\mathrm{C}_{5}$ sugars. The yields on butanediol and acetoin, on the other hand, are small compared to the free energy change of these reactions, but are still higher than those obtained with the recently isolated $P$. carbinolicus and $P$. propionicus 
(Schink 1983). Actually, they match well with the yield $(8.75 \mathrm{~g} / \mathrm{mol})$ obtained with $P$. carbinolicus in acetogenic coculture with an $A$. woodii strain unable to grow on butanediol itself. This mixed culture exhibits the same total fermentation pattern as strain Wo Bd P1 does in pure culture.

\section{Taxonomy}

The new isolate described in the present paper, strain Wo $\mathrm{Bd} P 1$, is a strictly anaerobic sporeforming bacterium which, by the current nomenclature, has to be classified as a Clostridium sp. (Buchanan and Gibbons 1974). It differs from any other homoacetogenic Clostridium sp. known so far by its unusual cell size and morphology and the range of substrates utilized (Table 1), especially by its inability to grow on $\mathrm{C}_{1}$ compounds or ethanol and by its capacity to grow on citrate or xylose. Moreover, position and shape of the spores, as well as the shape of the sporulating cells distinguish this isolate from the two species described. Therefore, a new species, $C$. magnum, is proposed which should be listed with group I of the genus Clostridium (Buchanan and Gibbons 1974).

C. magnum sp. nov. mag'num L. n. magnus big, referring to cell size.

Rod-shaped cells, $1.0-4.0 \times 4-16 \mu \mathrm{m}$ in size, slightly pointed at the ends. Motile by polar and subpolar flagella. Ageing cells form spindles with dark zones at the ends. Elliptical spores $(1.5 \times 2.5 \mu \mathrm{m})$ formed centrally to subterminally in ageing cultures, preferentially after growth on sugars. Gram reaction negative, also in young cultures. No outer membrane visible in ultrathin sections.

Strictly anaerobic chemoorganotroph. Fructose, glucose, sucrose, xylose, malate, citrate, 2,3-butanediol, acetoin, and (weakly) pyruvate used for growth. Acetate only fermentation product. No growth on $\mathrm{C}_{1}$ compounds, on ethylene glycol, ethanol, acetate, glyoxylate, glycolate, serine, lactate, oxalate, malonate, fumarate, succinate, oxaloacetate, glutamate, glycerate, glycerol, diacetyl, orotate, maltose, ribose, arabinose, starch, peptone, casamino acids, yeast extract. Gelatin or urea not hydrolyzed. Nitrate, sulfate, sulfite, sulfur, thiosulfate or fumarate not reduced.

Growth requires mineral media with a reductant. $\mathrm{NaCl}$ inhibits growth at $1 \%$, phosphate at $20 \mathrm{mM}$ concentration. No growth factors or vitamins needed. Selective enrichment from pasteurized sediment samples with 2,3-butanediol in carbonate-buffered mineral medium.

$\mathrm{pH}$ range: $6.0-7.5$; optimum at 7.0.

Temperature range: $15^{\circ} \mathrm{C}-45^{\circ} \mathrm{C}$, optimum at $30-$ $32^{\circ} \mathrm{C}$.

No cytochromes detectable.

DNA base ratio: $29.1 \% \mathrm{G}+\mathrm{C}$ (thermal denaturation).

Habitats: anoxic freshwater sediments and digestor sludge.

Type strain: Wo Bd P1, DSM 2767, deposited in: Deutsche Sammlung von Mikroorganismen, Göttingen.

Acknowledgements. The author is indebted to Professor Dr. N. Pfennig for support and valuable criticism, as well as to Waltraud Dilling for determination of the DNA base ratio and for electron microscopic characterization. Thanks are also due to Elisabeth Kayser for technical assistance in physiological experiments.

\section{References}

Adamse AD (1980) New isolation of Clostridium aceticum (Wieringa). Antonie van Leeuwenhoek J Microbiol Serol $46: 523-531$

Adamse AD, Velzeboer CTM (1982) Features of a Clostridium strain $\mathrm{CV}-\mathrm{AAl}$, an obligatory anaerobic bacterium producing acetic acid from methanol. Antonie van Leeuwenhoek J Microbiol Serol 48:305-313

Andreesen JR, Gottschalk G, Schlegel HG (1970) Clostridium formicoaceticum nov. spec., isolation description, and distinction from C. aceticum and C. thermoaceticum. Arch Mikrobiol $72: 154-174$

Bache R, Pfennig N (1981) Selective isolation of Acetobacterium woodii on methoxylated aromatic acids and determination of growth yields. Arch Microbiol 130:255-261

Balch WE, Schoberth S, Tanner RS, Wolfe RS (1977) Acetobacterium, a new genus of hydrogen-oxidizing carbon dioxidereducing, anaerobic bacteria. Int J Syst Bacteriol 27:355361

Braun M, Gottschalk G (1982) Acetobacterium wieringae sp. nov., a new species producing acetic acid from molecular hydrogen and carbon dioxide. Zbl Bakt Hyg I Abt Orig C3:368-376

Braun M, Mayer F, Gottschalk G (1981) Clostridium aceticum (Wieringa), a microorganism producing acetic acid from molecular hydrogen and carbon dioxide. Arch Microbiol $128: 288-293$

Buchanan RE, Gibbons NE (eds) (1974) Bergey's manual of determinative bacteriology, 8th edn. Williams and Wilkins, Co., Baltimore

Fontaine FE, Peterson WH, McCoy E, Johnson MJ, Ritter GJ (1942) A new type of glucose fermentation by Clostridium thermoaceticum $\mathrm{n}$. sp. J Bacteriol 43:701-715

Höhn-Bentz H, Radler F (1978) Bacterial 2,3-butanediol dehydrogenases. Arch Microbiol 116:197-203

Laanbroek HJ, Abee T, Voogd JL (1982) Alcohol conversions by Desulfobulbus propionicus Lindhorst in the presence and absence of sulfate and hydrogen. Arch Microbiol 133:178-184

Leigh JA, Mayer F, Wolfe RS (1981) Acetogenium kivui, a new thermophilic hydrogen-oxidizing, acetogenic bacterium. Arch Microbiol 129:275-280

Mayfield CJ, Inniss WE (1977) A rapid, simple method for staining bacterial flagella. Can J Microbiol 23:1311 - 1313

Pfennig N (1978) Rhodocyclus purpureus gen. nov. and sp. nov., a ring-shaped, vitamin $\mathrm{B}_{12}$-requiring member of the family Rhodospirillaceae. Int J Syst Bacteriol 28:283-288

Samain E, Albaniac G, Dubourgier HC, Touzel JP (1982) Characterization of a new propionic acid bacterium that ferments ethanol and displays a growth factor dependent association with a Gram negative homoacetogen. FEMS Microbiol Lett 15:69-74

Schink B (1983) Fermentation of 2,3-butanediol by Pelobacter carbinolicus sp. nov. and Pelobacter propionicus, sp. nov., and evidence for propionate formation from $\mathrm{C}_{2}$ compounds. Arch Microbiol 137:33-41

Schink B, Pfennig N (1982) Fermentation of trihydroxybenzenes by Pelobacter acidigallici gen. nov. sp. nov., a new strictly anaerobic, non-sporeforming bacterium. Arch Microbiol 133:195-201

Schink B, Stieb M (1983) Fermentative degradation of polyethylene glycol by a new, strictly anaerobic, Gram negative, nonsporeforming bacterium, Pelobacter venetianus sp. nov. Appl Environ Microbiol 45:1905-1913

Sharak Genthner BR, Davis CL, Bryant MP (1981) Features of rumen and sewage sludge strains of Eubacterium limosum, a methanol and $\mathrm{H}_{2}-\mathrm{CO}_{2}$ utilizing species. Appl Environ Microbiol 42:12-19

Stouthamer AH (1979) The search for correlation between theoretical and experimental growth yiclds. In: Quayle JR (ed) International review of biochemistry, vol 21, Microbial biochemistry. University Park Press, Baltimore, pp 1-47 
Taylor MB, Juni E (1960) Stereoisomeric specificities of 2,3-butanediol dehydrogenases. Biochim Biophys Acta 39:448-457

Thauer RK, Jungermann K, Decker K (1977) Energy conservation in chemotrophic anaerobic bacteria. Bacteriol Rev $41: 100-180$.

Tschech A, Pfennig N (1983) Growth yield increase linked to caffeate reduction in Acetobacterium woodii. Arch Microbiol (in press)

Widdel F, Pfennig N (1977) A new anaerobic, sporing, acetateoxidizing, sulfate-reducing bacterium, Desulfotomaculum (emend.) acetoxidans. Arch Microbiol 112:119-122

Widdel F, Pfennig N (1981) Studies on dissimilatory sulfate-reducing bacteria that decompose fatty acids. I. Isolation of new sulfate-reducing bacteria enriched with acetate from saline environments. Description of Desulfobacter postgatei gen. nov. sp. nov. Arch Microbiol 129:395-400
Widdel F, Kohring G-W, Mayer F (1983) Studies on dissimilatory sulfate-reducing bacteria that decompose fatty acids. III. Characterization of the filamentous gliding Desulfonema limicola gen. nov. sp. nov., and Desulfonema magnum sp. nov. Arch Microbiol 134:286-294

Wieringa KT (1940) The formation of acetic acid from $\mathrm{CO}_{2}$ and $\mathrm{H}_{2}$ by anaerobic spore-forming bacteria. Antonie van Leeuwenhoek J Microbiol Serol 6:251 - 262

Zeikus JG, Lynd LH, Thompson TE, Krzycki JA, Weimer PJ, Hegge PW (1980) Isolation and characterization of a new, methylotrophic acidogenic anaerobe, the Marburg strain. Curr Microbiol 3:381-386

Received November 3, 1983/Accepted November 22, 1983 